\title{
A NEW SPECIES OF LEPECHINIA WILLD. (LAMIACEAE)
}

\author{
JEFFREY A. HART
}

A systematic revision of the genus Lepechinia which consists of 36 species has recently been completed by me. Most of the species are native to tropical and subtropical highlands of Latin America with the exception of four species which occur in California, U.S.A.

While visiting the Ecuadorian highlands during my last collecting trip, around Vilcabamba I came upon another, yet undescribed species. The flowers of this new plants appear to be rather small when compared with the other members of the Section Parviflorae, which is restricted to andean South America, where these new plants belong. As a matter of fact, the size of the corollas, as noted, are the smallest in the entire genus. The plants are dioecious; the female (pistillate) flowers have somewhat larger calyces and smaller corollas than do the male (staminate) flowers.

\section{Lepechinia dioica Hart, sp. nov.}

L. mutica et L. mollis affinis sed foliis basi decurrentibus, calycibus constrictis distalibus, et inflorescentiis ramosissimis. Type: near Vilcabamba, Ecuador, 1700 m, Hart 1983 (holotype, $\mathrm{GH}$ !).

Shrubs 1-2 m tall. Leaf blades (Figure $1 \mathrm{~A}$ ) narrowly ovate, (4.0-)4.5-12.0(-14.7) $\times(1.4-) 2.0-3.8(-4.4) \mathrm{cm}, \mathrm{L} / \mathrm{W}$ ratio $2.5-3.9$; apices acute; bases obtuse and decurrent; margins serrate; adaxial surfaces (Figure 1 B) bullate, bullae $0.4-1.2 \mathrm{~mm}$ across, rounded and densely tomentose on top, sessile glandular hairs; abaxial surface densely pubescent. Petioles $0.5-1.8 \mathrm{~cm}$ long, villose. Inflorescence axes (4.8-)8.0-22.0 cm long, 5- to 9- (to 11-) branched, lowermost branch 0.4-0.6 times the length of the axis; verticillasters interrupted; floral leaves oval, 1.3-2.1 mm long, not exceeding the flowers in length, upper floral leaves caducous above; pedicels $0.3-0.4 \mathrm{~mm}$ long. Dioecious. Calyces at anthesis 
1.7-2.6 $\times 1.3-1.6 \mathrm{~mm}$, teeth acute, $0.3-0.8 \mathrm{~mm}$ long. Staminate plants: corolla $2.1-3.2 \times 0.9-1.5 \mathrm{~mm}$, abaxial lobe $0.7-1.7 \mathrm{~mm}$ long, other lobes $0.4-0.6 \mathrm{~mm}$ long, pilose patch between abaxial filaments (sparse to absent); filaments $0.4-0.9 \mathrm{~mm}$ long, anthers 0.3-0.4 mm long; ovaries $0.2-0.4 \mathrm{~mm}$ long, style $1.3-1.7 \mathrm{~mm}$ long, stigmas ca. $0.2 \mathrm{~mm}$ long; nutlets at most $0.2-0.4 \mathrm{~mm}$ long; calyx 3.4-4.5 mm long. Pistillate plants: corollas $1.7-2.7 \times 0.8-1.1 \mathrm{~mm}$, abaxial lobe $0.5-0.9 \mathrm{~mm}$ long, other lobes $0.3-0.4 \mathrm{~mm}$ long, pilose patch between abaxial filaments (sparse to absent); filaments ca. $0.2 \mathrm{~mm}$ long, anthers ca. $0.2 \mathrm{~mm}$ long; ovaries $0.3-0.4 \mathrm{~mm}$ long, style $1.3-2.2 \mathrm{~mm}$ long, stigmas ca. $0.2 \mathrm{~mm}$ long. Fruiting calyces (Figure $1 \mathrm{C}$ ) yellowish green to brown and slightly purplish tinged, subbilabiate, tube constricted distally, adaxially 3.4-4.8 $\mathrm{mm}$ long, abaxially somewhat shorter, tube $1.7-2.2 \mathrm{~mm}$ wide, teeth acute, the adaxial $0.3-0.6(-0.9) \mathrm{mm}$ and the abaxial $0.4-0.9$ $\mathrm{mm}$ long; veins 5 (to 7 ). Nutlets maturing to $1.8 \mathrm{~mm}$ long.

Distribution and Ecology. Southern Ecuador (Figure 1 D); dry terrain alongside roads and in disturbed secondary vegetation; 1700-2300 m; flowering from May through July.

Representative Specimens. Ecuador. Loja: near Vilcabamba, 2300 m, Hart $774(\mathrm{GH}) ; 1760$ m, Hart $1276(\mathrm{GH})$; near Vilcabamba, 1700 m, Hart $1983(\mathrm{GH})$ Holotype!; near Quilanga, 2280 $\mathrm{m}, \operatorname{Hart} 1358(\mathrm{GH})$.

Lepechinia dioica is a distinctive species recognized by its leaves which are lanceolate to ovate-lanceolate, have obtuse and long decurrent bases, and are densely and minutely pubescent on the adaxial surfaces; highly branched inflorescences with 5 to 8 secondary branches and caducous floral leaves; small fruiting calyces whose tubes are constricted distally; very small teeth $0.4-0.9 \mathrm{~mm}$ long, and 5 (to 7) veins; the tiny corollas $2.1-2.7 \mathrm{~mm}$ long; and dioecious breeding system. The epithet "dioica" alludes to the breeding system.

Lepechinia dioica is most closely related to $L$. mutica and $L$. mollis, and shares with them densely tomentose, ovate leaves with acute bases. It differs from them by its decurrent leaf bases; distally constricted, slightly purplish, much fewer 5- (to 7-) veined mature calyces; and generally more highly branched inflorescences. 

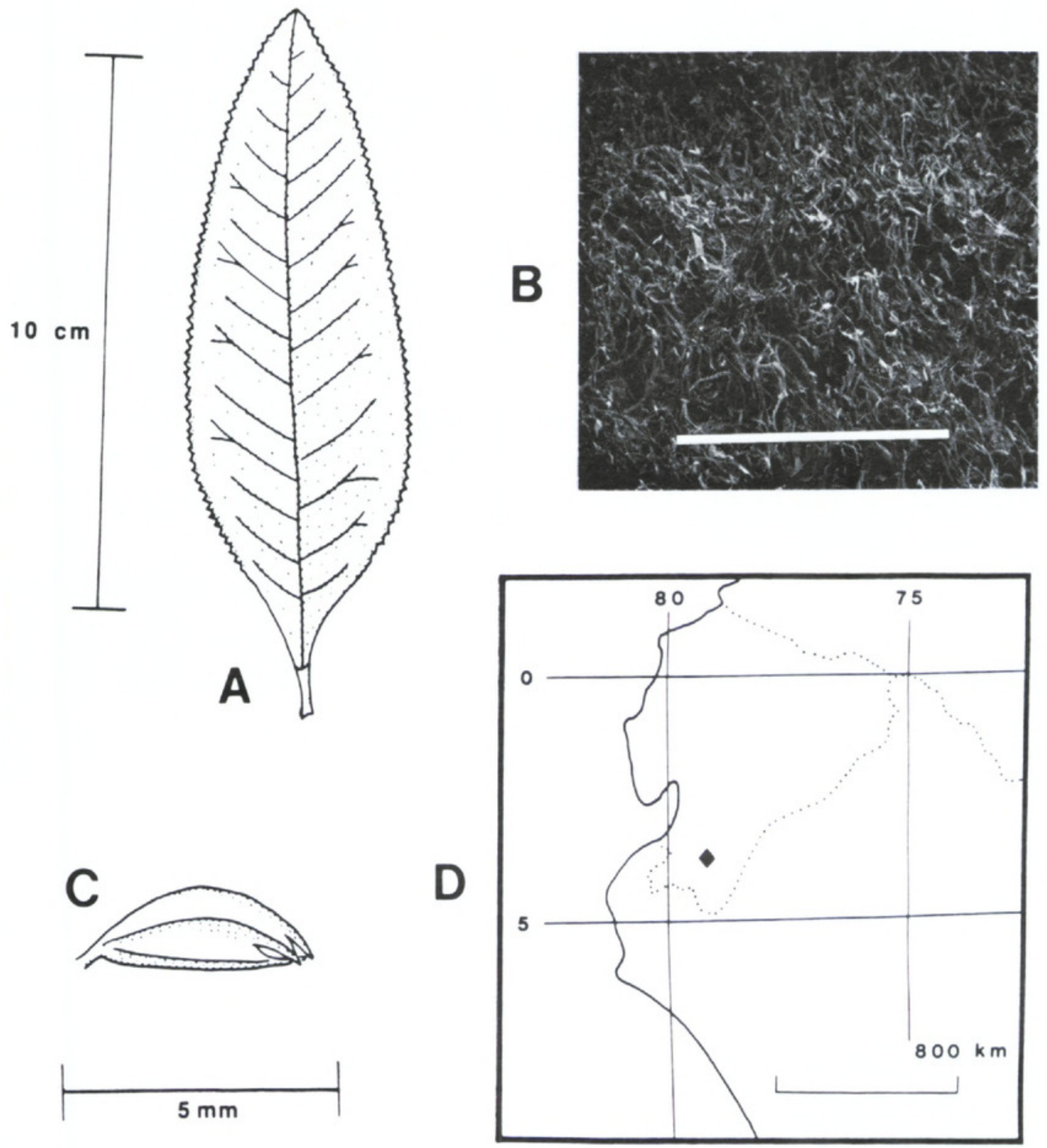

Figure 1. Distribution map and diagnostic characters of Lepechinia dioica. A, Leaf (Hart 1983); B, Adaxial leaf surface (Hart 1983) (bar $=1000 \mathrm{mu})$; C, Fruiting calyx, lateral view (Hart 1983); D, Distribution map.

\section{LITERATURE CITED}

Hart, J. A. 1983. Systematics and evolution in the genus Lepechinia Willd. (Lamiaceae). Ph.D. dissertation. Harvard University.

Hart, J. A. 1984. Evolution of dioecy in Lepechinia Willd. Section Parviflorae. (Submitted for publication). 


\section{$2 \mathrm{BHL}$ Biodiversity Heritage Library}

Hart, Jeffrey A . 1985. "A New Species of Lepechinia Willd. (Lamiaceae)." Botanical Museum leaflets, Harvard University 30(2), 85-87. https://doi.org/10.5962/p.168671.

View This Item Online: https://www.biodiversitylibrary.org/item/31877

DOI: https://doi.org/10.5962/p.168671

Permalink: https://www.biodiversitylibrary.org/partpdf/168671

\section{Holding Institution}

Missouri Botanical Garden, Peter H. Raven Library

\section{Sponsored by}

Missouri Botanical Garden

\section{Copyright \& Reuse}

Copyright Status: Public domain. The BHL considers that this work is no longer under copyright protection.

This document was created from content at the Biodiversity Heritage Library, the world's largest open access digital library for biodiversity literature and archives. Visit BHL at https://www.biodiversitylibrary.org. 